Intertextualizing Interactive Texts for Critical Thinking: A South Korean EFL Experience

Ranamukalage Chandrasoma University of Technology, Sydney. Australia

Ranamukalage.chandrasoma@uts.edu.au

Lalith Ananda

University of Sri Jayewardenepura, Nugegoda. Si Lanka mlalithananda@gmail.com

Publication date: August, 2017

Correspondence should be addressed to Ranamukalage Chandrasoma, School of Education, Faculty of Arts and Social Sciences, University of Technology Sydney. Email:

ranamukalage.chandrasoma@uts.edu.au 


\title{
Intertextualizing Interactive Texts for Critical Thinking: A South Korean EFL Experience
}

\begin{abstract}
In the past three decades or so, the conceptual rigour of intertextuality has exercised enormous influence on pedagogical practices. In this context, intertextuality can also be used as a means of harnessing students' critical stances that are crucial for teaching language skills. Based on eight qualitative student interviews at a university in South Korea, this article introduces a case study in which EFL students develop their critical thinking by responding to an interactive (oral/visual) text in a listening comprehension/speaking class. Critical thinking is a specific learning outcome of this EFL program. A typology of intertextuality has also been introduced here to illustrate how various intertextual links can stimulate students' critical observation. The theoretical framework of this research is informed by the concept of intertextuality which prescribes that texts are populated with other texts, and that they have textual as well as contextual links with each other. As the findings of this empirical investigation demonstrate, Discourse emerging from intertextual resources could be utilized as a textual space where, with appropriate pedagogical intervention, students have immense opportunities for developing critical stances.
\end{abstract}

(Keywords: critical thinking, Discourse, EFL instructors, EFL pedagogy, interactive intertextuality, interactive texts, intertextuality) 


\section{Introduction}

Intertextuality is a concept that has long been associated with literary studies; however, it is also a pedagogically significant resourceful site where students can be made aware of critical thinking. Premised in this macro context, this research-based article has two main objectives. First, it explores how instructors can productively utilize intertextuality as a strategy for developing students' critical observation in an EFL listening/speaking class. Here, students have opportunities for participating in several discourses through intertextual links. Unlike in a reading or writing class, students in a listening/oral production class can be engaged in collaborative learning such as group work, question sessions with ease, and instructors can guide students in more flexible ways paying individual attention where necessary, ensuring optimal student interaction. Second, it demonstrates how students can develop their critical stances in response to an interactive text in which Dr Martin Luther King Jr. (henceforward, King) delivers his influential speech 'I have a dream' (King, 1963). These two objectives, however, are mutually constitutive in the sense that they integrate both teaching and learning. As evidenced by this research, instructors can provide texts that are firmly anchored in student identities, and such texts strongly motivate students to exercise their cognitive and metacognitive faculties in and beyond the comfort zones.

People's identities n a broader social context have been extensively researched (Gray, 2006; Ivanic, 1998; Knobel, 1999; Norton, 2000) and some scholarly journals in the social sciences are devoted to this complex issue. Student identities are by and large conditioned by their discursive practices where they consume a myriad of visually mediated texts owing to the ubiquity of new technologies of communication (Chandrasoma \& Lee, 2013; Gardner \& Davis, 2013; Prensky, 2001). For the purpose of this research, student identities can be classified into four discernible types contingent on lived experiences: biographical (e.g. culturally defined identities such as ethnicity, religion, colour, caste); social (e.g. social practices such as participation in celebrations, ceremonies, and social events); discoursal (e.g. 
discursive practices of the discourse community of university students: use of televisual texts for communicative purposes, attending lectures, taking notes using in-built digital cameras of sophisticated cell phones, participation in demonstrations and acts of protest); ideological (e.g. belief in and attitudes to issues of ideological significance at conceptual and interpretive levels: politicization and commodification of education, human rights, political systems, freedom and oppression). The significance of this phenomenological approach to student identities and the resultant critical thinking process becomes evident in our research participants' response to visually mediated texts that establish reciprocal relations with their identities. Such orientations invariably denote a gradual shift on the part of students from texts/contexts to concepts. In King's speech, grievances of the under privileged blacks and the atrocities committed against humanity are voiced in unequivocal terms. Today, young student activists emerge from many countries and they play an important role in organizing demonstrations against social injustice, political oppression, environment pollution in particular and any form of discrimination in general. These identities are closely associated with concepts, and any conceptualization process necessarily entails a strong element of critical thinking. For example, to convert visually conveyed information into concepts, students have to make critical judgments which may involve comparison, elimination, contestation, forming informed opinions, and many more besides. In contrast, some teaching sequences of reading comprehension texts can be viewed as dead ends. For example, reading comprehension questions often with predictable answers make students cope with a body of content knowledge within the rigid boundary of a target text. When looking for answers in these situations, students invariably reproduce lexis, structure, and the required content found in the target text itself, bereft of any critical orientation. This convenient strategy can be more debilitating than facilitating the critical thinking process, indeed.

In the context of this research, we take into consideration five main factors that constitute critical thinking: 
- form informed as well as hypothetical judgments by analyzing rather than just describing.

- problematize issues/situations from different perspectives.

- engage in disinterested and impartial observation.

- substantiate claims with evidence

- demonstrate primary academic voice (contribute something original on their own)

The nexus between critical thinking and various modes of texts (visual, written, oral, and interactive) can hardly be overlooked. In interactive texts, we can witness a combination of two or more modes of texts: oral, visual, and written. In our contemporary contexts, digital agility of social actors has become increasingly visible as a result of the new technologies of communication. In these environments, establishing textual relations is an integral part of human communication as evidenced by a variety of social practices and discursive practices ranging from shopping, entertainment, web browsing, cooking to travelling, teaching, note taking, and texting, and the list is not exhaustive. On the strength of their communicative and interpretive potential, these practices are of paramount importance for language pedagogy in particular. For example, students can be encouraged to develop their critical stances by discovering intertextual relations and their cumulative significance in forming judgments. This perspective may aptly be called 'interactive intertextuality' which sheds much light on the undeniable nexus between knowledge of intertextual manifestations and their impact on critical thinking. In other words, our prior knowledge, values attitudes, beliefs, and experiences are a significant dimension to the scrutiny of any intertextual projections since they have a direct bearing on the meaning making process.

Interactive intertextuality in the context of lower intermediate level EFL students refers to a concept where texts and their contexts signifying affinities with various other texts and contexts are foregrounded by means of the interactive behaviour of two textual modes: 
oral and visual. At higher levels, (e.g. intermediate and upper intermediate), written texts could also be accommodated. New technologies of communication in particular can facilitate the use of interactive text types such as video clips, documentaries, films, television programs, electronic advertising. The following are the salient features of interactive intertextuality:

- Manifestation of visually mediated interactive texts (e.g. speeches, documentaries, video clips, accompanied by intertextually rich visual texts)

- Utterances concurrently linked to associated texts

- Intertextually realized flashbacks to emphasize or highlight a particular issue referred to in an oral text

- Emphasis on Discourse (as explicated in Gee, 1996)

- Presence of primary interactive texts (PIT) and secondary interactive texts (SIT)

- Culturally appropriate texts

Texts that satisfy all or some of the criteria listed above may not be readily available or accessible. Instructors, therefore, have to scrutinize visually mediated texts that are suitable for the level of their students.

Interactive intertextuality enables instructors to transcend traditionally cherished boundaries of a text at four levels: text level (written, oral, visual, interactive), extrasentential level, phrase level, and word level. Productive use of this concept is largely contingent on pedagogically sound strategies catering to stimulate students' interest in interactive texts (e.g. provision of prior knowledge, introduction of effective questioning techniques, organizing group work, and selection of appropriate resources with multipleembedded intertextuality).

Primary interactive text (PIT) is the initial target text. For example, King's dream speech itself is the PIT. We as spectators can also watch the physical presence of King's 
audience and a series of flashbacks which contain strong textual potency. This phenomenon may be called the secondary interactive text (SIT). Both PIT and SIT vindicate the addresseraddressee dialogism introduced by Bakhtin (1986). For example, the presence of white people in SIT is equally important as King's references to racial segregation in PIT. These intertextually rich texts become more prominent when they are visually mediated using new technologies of communication.

The extent of intertextual intensity becomes evident if we compare the video of King's dream speech to a live telecast of a cricket match. The former is intertextually rich in the sense that it contains explicit references to a series of intertextually fortified strands of texts which provide students with intertextually invigorating experience whereas the latter focuses on the players' performance accompanied by the remarks made by the commentators, and the advertisements epitomized by various logos and brand names. As far as critical thinking is concerned, the role played by intertextuality here is a mediocre one. Cognitive faculties of the spectators watching the cricket match may be centred on two main planes at one level, it would be a case of 'who is or who is not going to win?'; at another level, 'who should or who should not win?'. Hence, this interactive text by and large appeals to adrenaline experience. In contrast, a strong element of critical thinking is required to comprehend King's dream speech and the associated intertextual resources. The categorization of intertextuality that precedes the discussion section of this article is hinged on the eight qualitative student interviews that reveal students' propensity to dwell on a variety of Discourse derived from intertextual relations.

As evidenced by empirical research (McCarthy, 1991; McCarthy \& Carter, 1994; Nunan, 1993), integration of Discourse into language teaching by utilizing authentic textual resources can facilitate the learner to acquire critical thinking skills. For the purpose of this research we are influenced by two scholarly propositions of discourse: first, Gee's (1996, p. 131) explication of discourse with a capital ' $D$ ' as socio-linguistically and politically oriented 
acts of communication and their interrelations and possibilities of extensions in a variety of texts, and second, Carter's view that discourse is a 'communicative product' that extends beyond sentence level (1993, p. 23). We, therefore, recognize that intertextuality contributes substantially towards enriching extra sentential dimensions of texts which are an integral part of Discourse. As far as this research is concerned, such Discourses are filtered through intertextual links emerging from an interactive text. It should be noted that adroit manoeuvring of students' towards a target Discourse in a text is largely dependent on the instructors' resourcefulness and students' prior knowledge of textual capital. Hence, when students' prior knowledge is considered inadequate, there is a need for providing such knowledge in the form of pre-listening activities targeting content, language use, terminology and pronunciation.

\section{Literature Review}

In general, intertextuality is a concept which problematizes the autonomy of texts since texts are always populated with and dependent on other texts for communicative purposes in a space where authors' presence is nebulous. Any investigation of the theoretical apparatus of intertextuality may lead to the works of several influential theorists: Althusser, (1977), Bakhtin, (1981, 1984, 1986), Barthes (1977, 1981), Kristeva (1980, 1984), and Saussure (1974). Barthes' notion of 'the death of the author' (1977, p. 148) clearly signals the futility of viewing texts as the sole property of an individual. He also refers to the infinite variety of 'connections and associations' that intertextuality can provide (1981, p. 39). Hence, every utterance is intertextually anchored and authored somewhere in an infinite spectrum of Discourse (Barthes, 1977). Similar views were expressed by Baudrillard (1993) in relation to the production of goods.

Bakhtin's explication of dialogism (1981) has strong overtones of intertextuality voiced by Kristeva in the sense that his theory recognizes the existence of multiple voices in texts as opposed to the monologic nature of texts promoted by Saussure (1974). As Bakhtin 
(1986) observes, readers, speakers, listeners, and spectators of texts can transcend the boundaries of textual manifestations to embrace contextual links that are both realistically and hypothetically defined. The former refers to contexts based on social situatedness and real experiences whereas the latter denotes plausible contexts perceived on a conjectural basis. Bakhtin further suggests that these two textual parameters should be primarily construed as the epistemology of textuality realized by individuals' prior knowledge. He also focuses on the 'latent' dimensions of utterances $(1984$, p. 90$)$ of oral texts to accommodate gestures, tone, silence and other metalinguistic nuances and subtleties. Bakhtin's (1984; 1986) notion that utterances resonate with various other utterances and manifest themselves as texts, real contexts, and hypothetical contexts is the theoretical framework within which we analyzed students' oral texts, and also conceptualized intertextuality in this article. Accordingly, a particular text can make meanings to people in terms of its textual as well as contextual references and their interdependence. Boundaries of texts in this sense are porous, and susceptible to the sense and sensibility of the reader/listener/speaker/spectator. What is implied here is that readers/listeners/speakers/spectators have to negotiate meaning in texts and contexts that are realistically and hypothetically defined behind the huge backdrop of historicity. Thus, intertextuality straddles texts and contexts to define and redefine moments of utterances, and also extends its frontiers beyond Bakhtin's dialogism based on the addresser and the addressee. For example, peripheral to King's dream speech, listeners/spectators are compelled to conceptualize the behaviour and textual characteristics of his audience as well. In other words, we notice how multiple voices of texts concurrently manifest themselves within and beyond the intertextual parameters of a PIT.

It is noticeable that in the last two decades, scholarly focus on intertextuality has largely been on two aspects: first, its epistemological dimensions: that is how intertextuality is understood to bring out desired meanings, what constitutes intertextuality, and why writers/speakers use intersexual resources in literary texts (e.g. Appadurai, 1996; Gray, 2006; 
Nielsen, 1994), and second, some scholars' predilection for investigating issues of sociopolitical interest in the contexts of intertextuality (e.g. Allen, 2000; Fairclough, 1995; Gee, 1996; Klein, 2005; Kline, 1992).

A closer perusal of the literature in peer-reviewed journals in English would reveal the paucity of scholarly work devoted to analyzing the role of intertextuality in fostering students' critical thinking among EFL learners. Some scholars (Alagozlu, 2007; Chi, 1998; $\mathrm{Yu}, 2013)$ report on EFL university students' ability as readers/writers to comprehend intertextual links. Another investigation focuses on the contribution of intertextuality toward promoting scientific understanding among primary students (Christine et. al. 2002).

Although the significance of developing critical stances among students in EFL classes has been copiously emphasized in the literature (e.g. Atkins, 1997; Davidson, 1998, McKinley, 2013; Oster, 1989), the role of intertextuality as a productive site for enhancing students' critical thinking still remains an under-researched area of critical pedagogy. Critical pedagogy views classroom as a socio-political institution where politics of education, culture, knowledge, text and identity are intermingled at Discourse level (Pennycook, 1990) while the accompanying relational contours of knowledge which implicate the learner in the outside world can be interpreted in terms of contestation, consensus, expansion, or compromise through critical thinking. Hence, critical thinking is an essential component of critical pedagogy.

Judging from the findings of this research, it is evident that intertextually rich texts can dramatize episodes of historicity with their multifarious meta-representational content. They can also be directly related to our own contemporary contexts. More importantly, they can persuade the consumers to make hypothetical propositions based on textual links. Interactive intertextuality facilitates cognitive focus on such intertextually realized sociohistorically significant moments and scenarios. 


\section{Research Questions}

The research questions were designed to establish a clear focus on the topic as explicated in the abstract:

- What role can intertextuality play as a pedagogical strategy in the context of EFL programs geared to teaching critical thinking?

- How do students develop their critical stances by responding to an interactive text with intertextual references?

- How can we work towards a typology of intertextuality in the context of developing students' critical stances?

\section{Interview Questions}

The interview questions were framed following a deductive approach focusing on the avenues for presupposition and inference in order to achieve several objectives that highlight the significance of collecting vital data for this research: elicit factual and intertextually rich information from the participants, enhance critical thinking through such information, extend their critical thinking beyond the Discourses manifest in the target text, assist students by providing cues where necessary in developing critical stances, and encourage students to provide evidence.

We have made interview questions more conversational and open-ended (see Appendix). Although the appendix contains some standard questions selectively used for interview purposes, we often deviated from them depending on the level of response from each participant. By means of short questions, statement questions, question tags, prompts, and cues, we were able to induce students' critical stances.

\section{Data Collection Protocols}

The data for this research were derived from three sources: scholarly work on intertextuality, our own professional experience, and eight qualitative student interviews. The 
data gathered here from the interviews reflect our participants' attitudes, concepts, beliefs, and practices in response to the interactive text.

When selecting the research participants (non-native speaking students of English), we thought that it was possible to have a relatively homogeneous group of students based on their performance in all the four macro skills: reading, writing, speech, listening. We therefore opted to select eight students who obtained the highest grades out of 418 students at the entry level test for the EFL course. The rationale behind selecting this number was that eight subjective interviews could be manageable in the textual space available for this article.

The constant shift from a metaphorically charged language to an ordinary and mundane use of language is a prominent feature in King's speech. Because of this reason, on the day before the video session, we introduced as a pre-listening activity some words and phrases that might help our students to comprehend King's speech (e.g., emancipation proclamation, crippled by the manacles of segregation, undeniable rights, defaulted, prodigious hilltops, nullification). We explained the meanings of them providing easily comprehensible contexts. Also of importance is the fact that King's speech has two crucial aspects as far as textual modes are concerned: his emotionally charged and rhetorically fortified utterances and the eloquent visual images as part of the interactive text. Considering the comprehension difficulties for EFL students arising from the concomitant use of these two textual modes, the participants were given the opportunity to watch the video twice in class with a ten-minute break in between. When they watched it for the second time, they were asked to take notes on what they considered important. On the same day, we interviewed each participant separately for approximately 30 minutes at a mutually arranged time. These interviews were audio-recorded and subsequently transcribed. During the interview process, we often used open-ended questions to elicit detailed responses, and the participants were allowed to refer to their notes in case they had forgotten some details relating to the video. 
For the purpose of data analysis in working towards a typology of intertextuality, we used the qualitative text analysis software (QDA Miner) which lends itself to the interpretation and grouping of our participants' comments, both analytical and descriptive, made at the student interviews in this research.

Critical thinking, both as a concept and as a competency, defies quantifiable analysis since it belongs to intangible cognitive domains of students. The qualitative research paradigm is well suited to examine texts, contexts, social actors, and their interactions in more tangible ways, and to administer interview questions that demand rich description (Patton, 1990). This approach also helped us analyze values, attitudes, beliefs, and experiences of our students. Other dimensions such as the provision of prior knowledge in terms of linguistic and epistemological entities and eliciting information from students on an interactive text with immense descriptive and narrative intensity appeal to a qualitative methodology. Explication of pedagogical constraints referred to in the discussion section also lends itself to a qualitative approach.

King's dream speech has proved to be productive for this research for several reasons: first, it is an interactive text that highlights a controversial topic in his contemporary political environments along with corresponding Discourse, second, it contains two interactive texts: King's speech (PIT), and the physically present audience he is addressing (SIT) which includes flashbacks as well, third, it is easily comprehensible to students in South Korea by virtue of their exposure to American English, fourth, these students living in a technologically advanced country are more interested in visually mediated interactive texts, fifth, this emotionally charged political speech may appeal to any audience regardless of their preferences or differences, and sixth, the propositional content of his speech fits into the curriculum of the EFL program our research participants were following.

To determine the extent to which a text or context can be intertextual is a vexed issue. From a Barthesian point of view (1981), it is the impact of the iterative manifestations of 
intertextuality that dictate terms to an alleged author or speaker; however, in our research only explicit references to intertextuality were taken into consideration. For example, if a student compares Dr King's speech to a church sermon, then it is considered to be an explicit instance of intertextuality. On the other hand, if someone remarks that Dr King's speech is too long to be good, then it does not come within the purview of intertextuality although an element of remotely connected comparison exists for this comment to be made. EFL students can be benefited from this lucid approach to intertextuality.

The EFL program related to this study contains a competency-based curriculum which mandates that students should, as part of the requirements of the course, demonstrate their analytical skills and critical thinking in their assignments, both written and oral. Moreover, content areas of the listening/speaking tasks include issues of political, social, and cultural significance in a variety of contexts. Since these students are rated as lower intermediate level based on their competencies in the four macro skills, both teaching and learning critical thinking can be challenging tasks.

\section{Ethical Considerations}

The research participants provided their consent in writing for the voluntary participation in this research. It was clearly spelt out in the consent form that the participants' identity (name, age) would not be revealed before, during, and after the research, and that each participant would cooperate with the researcher to face a 30-minute interview at a mutually arranged time. The students were informed of the primary purpose of this research: exploration of different ways in which students can be made aware of critical thinking using the resources of King's dream speech.

\section{Participants}

Eight first-year university students enrolled in three-year BA degree programs (professional cuisine, hospitality management, food hygiene, architectural design, railroad structure and design) at a South Korean university participated in this research. All of them 
were concurrently following a six-month integrated language skills course (EFL) at lower intermediate level where listening comprehension/speech was a component. The participants ranged in age from 19-22 and they were all fresh from their high school environments. It is pertinent to note here that these students come from a culturally and linguistically diverse background, and that they have varied disciplinary orientations (EFL classes at this university are multidisciplinary). Out of them four were Koreans and the others from different nationalities. They were identified by their pseudonyms: Clara (Chinese), Joe (Korean), Kim (Korean), Ninh (Vietnamese), Park (Korean), Steven (Thai), Timothy (South African), and Yook (Korean).

It was observed that during pre-university schooling, most of the texts the research participants produced as part of writing competencies in their first languages were confined to short narratives devoid of critical perspectives. In fact, the impact of this minimal exposure to analyzing texts using critical stances was strongly evidenced by the written texts they produced in class as part of the EFL course. They contained predominantly factual information, and were more descriptive than analytical. Accordingly, more listen/speakbefore-write activities could enable students to think critically and develop an analytical mind.

\section{Towards a Typology of Intertextuality}

Typological observations generally involve a deductive process where propositions are made on the basis of already existing entities. Some scholars have introduced various typologies of intertextuality in different academic contexts. Exploring the centrifugal dimensions of intertextuality in disciplinary/interdisciplinary domains, Chandrasoma et al emphasize the significance of conceptualizing student plagiarism in the academy under two types of intertextuality: transgressive and non-transgressive (2004). Based on referential characteristics, Fairclough (1995) identifies two types of intertextuality: manifest and constitutive. The former dwells on literary devices such as irony, allusion, hyperbole whereas 
the latter includes physical aspects of texts such as generic features and structure. According to Miola (2004), intertextuality can manifest itself in seven ways in the context of early modern literature: revision, translation, quotation, sources, conventions, genres, prologues.

Drawing on the empirical evidence gathered from this research, and also from our own observation, the typology we have introduced here is rooted in the pedagogical value of intertextuality which consists of four elements: intertextuality transcends traditional boundaries of any text; an element of critical thinking is required for synthesizing intertextual resources in and beyond a text enveloping political, social, historical, and cultural dimensions; depending on the perspectives of listeners/speakers/readers/spectators, several types of intertextuality can stem from a text; instructors can gain pedagogical benefits from harnessing students' critical orientation towards a particular type of intertextuality. Accordingly, we have identified five types of intertextuality that entice students into critical thinking: apparent, conceptual, connotative, extended, and hypothetical.

\section{Apparent Intertextuality}

Apparent intertextuality refers to more visible and easily comprehensible features of a text (e.g., visual images like posters). Some of our participants dwelt on posters and slogans at length, and were able to establish intertextual links in the process of their critical thinking. Kim, Park, and Yook commented on the more visually prominent aspects of the video, especially the presence of demonstrators carrying posters and shouting slogans, a phenomenon associated with their social identity in South Korea. Immediately before his emotionally charged speech, King was walking with the demonstrators holding placards exhibiting the slogans: 'We Demand Jobs Now', 'End Police Brutality Now'. Demonstrations where protesters carry placards/posters to unleash their anger have been a common feature in emancipatory discourse in many parts of the world. While referring to the slogans, Yook commented on the anti-nuclear activists who launched a protest in Seoul in March 2012: 
Excerpt 1.

...the posters are important... They show angry crowds and help fix problems... In Seoul, against nuclear testing ... like North Korea, we had a problem like that and they fix problems. I like the posters in the speech.... They show unemployment and problems with the police... that's a problem, very important problem...

His reference to Discourse surrounding nuclear testing and also the strained relations between South Korea and North Korea are significant here since they are intertextually realized and identity oriented. Concentrating mostly on the slogans and placards to make his critical judgments, he further elaborates on the sufferings of the black people who were at the mercy of the white. Similar to what Yook said, Kim and Park also focus on the high incidence of students carrying posters as acts of protest during demonstrations in Seoul. When asked why only students often carry posters, Park said,

\section{Excerpt 2.}

It's because they are active...And they can have big crowds on the streets...They also have free time to do....There are good things and bad things. Good because we can win, bad because they make trouble for people. Trouble for people around and traffic situation...

Park was able to proceed beyond the context to make some critical observations based on his intertextual intimacy with the visual images in King's speech. Thinking deep into this discursive practice, he distinguishes between 'good' and 'bad' aspects of demonstrations. For Kim the posters and the slogans speak eloquently of the situation in America at the time of King's speech:

Excerpt 3.

...part of US history and people shout with posters... The crowd helped his speech ... and supported him... We have in Korea sometimes the same...We need to shout to get what we want... and action is clear there always... 
Here, Kim makes some critical observations by comparing the situation during King's time to contemporary situations in South Korea. In response to our question: "Why do people carry posters or display them in public places?' Kim said,

\section{Excerpt 4.}

People carry posters and display them because that is strong message, and they can win...It is a... like a language to tell other people... with big voice and young people like them. They write in big letters... and they are powerful...

Kim's critical observation that posters are in fact a language that people can understand easily and that they vehemently reflect the voice of the demonstrators exhibits his critical aptitudes. Similarly, the portrait of Abraham Lincoln was a strong signifier that led to critical thinking through apparent intertextuality as exemplified by Ninh's comments: ‘ He explains problems... show[s] examples like Abraham Lincoln's image to the people around the world...' Such visual manifestations lure students into the realms of critical thinking, indeed, and are more appropriate for students with poor listening skills and lower level oral production.

\section{Conceptual Intertextuality}

Conceptual intertextuality foregrounds concepts in a particular text. Some participants developed their critical stances within a framework of intertextually realized concepts. Clara, for example, referred to the concepts of freedom, struggle, and education, whereas Steven focused on discrimination, injustice, and punishment. Both of them were able to relate these concepts in a broader social context based on their own cultural and political orientations. When asked about the most important issue in King's speech, Clara hesitated and then used the words 'freedom' and 'struggle'. This two-word-summary in itself is an outcome of critical thinking. Later she responded to the questions in brief:

\section{Excerpt 5.}


Freedom and struggle... They are important. I know in China we had students' riots. I have seen videos...in Tiananmen Square and that helped some... I think some students, like refugees went overseas to some countries...like Canada, USA, and Australia for a better life politically and economically... I think the man is brave, and very brave... This shouldn't be his dream. Surely, this should be a reality...... saw black and some white people together...because there is some good reason for the man to talk... White people are there to support him... they are also brave...

Focusing on historical perspectives, Clara obviously tried to analyze the speech in relation to China which is a context familiar to her. With her reasonably acceptable oral proficiency in English, she was critical enough to comment on the 'better life, politically and economically' of the students who left China for Canada, the United States, and Australia as refugees during the Tiananmen Square riots back in 1989. In fact, her reference to the videos on Tiananmen Square is intertextually realized through her desire for comparison. She also repeated the word 'brave' several instances, and the speech is something incredible to her, again in the Chinese political contexts. More importantly, Clara develops her critical stances by referring to the presence of white people among the blacks as a very striking phenomenon. For Clara not only King was brave; the white people in the audience were also brave. From her critical point of view, it demonstrates the fact that King's speech is based on genuine reasons. More importantly, the use of evidentiality and modality (This shouldn't be his dream. Surely, this should be a reality) denotes Clara's predilection for critical scrutiny.

At one point, Clara transcends the boundary of King's speech by referring to women's emancipation:

Excerpt 6.

... Women's freedom is important. This topic is as important as the political issues...Woman still cannot gain freedom. In politics they have limited attention and we need more brave woman leaders...International pressure is important. Developing 
countries can learn from international pressure... and surely freedom will come little by little...

Clara's reference to women's freedom and the need for more 'woman leaders' is a distinct indication of her familiarity with feminist Discourse. Clara here proceeds beyond the target text to be critical of women's current situation in a broader social context. When asked about King's references to democracy, Clara further exhibits her critical aptitudes:

\section{Excerpt 7.}

...It is people power and they can do anything... but in some countries they go as democracy but really they are the opposite...they just only by name democracy... and as a result people suffer and no fair justice...They must fight for freedom...

Here Clara defines democracy using a familiar phrase 'people power' widely disseminated as part of political Discourse through the social media in our contemporary contexts. Then she attempts to capture the arbitrariness of the term 'democracy' since in some so called democracies it does not seem to manifest itself as a true reflection of its intrinsic characteristics. For her, such distortions can be detrimental to social justice, and people are often at the mercy of the ruling powers.

In much the same way, Steven was eager to talk more about the issue of social justice which is one of the major themes of King's speech:

Excerpt 8.

...I mean a lot of people have similar problems like injustice, discrimination. I mean no justice for them. Some people, some politicians in some countries, they try to punish people for nothing...OK, He explains the problems beautifully...This is something going on in many parts, countries I mean...So there will be problems like this and also leaders like him to explain things... like Nelson Mandela and Gandhi...

Steven compares King to Gandhi and Mandela who struggled to achieve political freedom in South Africa and India respectively. His reference to 'some politicians in some countries' signals intertextual connections in a global context. Based on King's explanations, he builds 
up his critical stances and makes some conjectural propositions to mean that similar situations and leaders will emerge in many parts of the world. When asked about the dreams and realities, Steven's response was a critical one, too:

\section{Excerpt 9.}

OK, the gap is very wide and ... political leaders they generally don't mean what they say and they catch the opportunity whatever way and so it is a trick in politics, I mean cheating people. OK, However, King is different and he repeats dream several times and I mean it is something too far to be a reality... However, He is positive about his dreams. First he tries to win the confidence of the people. Then he talks about his plans, future plans...

Steven rationalizes the discrepancy between dreams and realities in politics, and considers King as an exception. Using sequence markers (first, then), Steven further demonstrates his critical awareness through organizing ideas in terms of logical relations. This comparative analysis of King in political Discourse, perhaps propelled by Steven's mental reprints, vividly explicates his critical orientation and also the overwhelming interest in this interactive text.

While fathoming the depths of King's speech, Timothy was able to deconstruct the target text in order to expose the leaders who are not 'genuine' in their utterances: '...but in some countries, leaders are not real leaders. They give a false picture, not genuine.' His critique of people who masquerade as genuine leaders bears ample testimony to his critical observation.

\section{Connotative Intertextuality}

The tone of a particular oral text can also lend itself to intertextual relations. Here we notice that the connotations of a text are potent enough to produce intertextual links with other texts, and are therefore part of textual resources for building up critical stances. These may be identified as 'connotative intertextuality'. The establishment of connotative intertextual links is mostly related to and contingent on one's affective dimensions. Closely 
linked to this is the rhetorical intensity of King's speech (Zheng, 2014), which enabled some of our participants to feel the pulse of his message even without understanding some contents of the speech.

King's speech has strong connotations of religious Discourse. For Ninh, King was a man of integrity. He responded to our questions while concentrating on how King substantiated his claims with evidence:

\section{Excerpt 10.}

He's an honest man. He explains problems... show examples like Abraham Lincoln's image to the people around the world... I like his style like a priest so he can win people... Yes, the tone of his speech very useful for his speech.

Here the very act of 'explaining problems', often accompanied by the rhetorical intensity of King's speech has attracted the attention of Ninh. King's speech in most parts resembling the tone of liturgical utterances not only reminded Ninh of the church sermons but it also persuaded her to be critical enough to comment on King's priest-like role as a deliberate strategy to attract religious-minded audiences. Her reference to Abraham Lincoln is a typical example of intertextuality in King's speech that highlights the role of democracy in liberating people from oppressive regimes.

In reply to our question about the message King conveys to the audience, Joe pointed out King's use of anaphoric utterances:

\section{Excerpt 11.}

... He was repeating many times about the dream...that is good and powerful... that is important... He repeats it and it stays in our mind forever...It is a strong message and it is very good summary... For him, King's use of repetition was the most important aspect. Joe, a reticent student, was unable to comprehend factual details in the speech. Obviously he was attracted by the sonorous tone of the iterative sentences.

\section{Extended Intertextuality}


Extended intertextuality gives rise to the formation of intertextual chains that reflect the ways in which students further intertextualize the textual links similar to the hyperlinks on the Internet. While discussing the demonstrations held in Washington, Timothy was able to extend intertextual links to the clashes in Pretoria in his home country, South Africa, and then to global contexts. His intertextualization process locates the political upheaval that took place in Pretoria which he had read about in a history book used in his High school back in South Africa. He further commented that Mandela was greater in many ways than King:

\section{Excerpt 12.}

...He's like Mandela and Castro, but Mandela was more active and a dedicated leader. I've read in... history books in high school ... how Mandela led the struggle. This has happened in many countries in the past... Future politicians should learn from their lessons... Some are very stupid and rubbish. Even some religious leaders are corrupt... but in some countries leaders are not real leaders. They give a false picture, not genuine... They say one thing and do another... They only show they are great... This video shows us past events and how they connect with the present...

According to him, Mandela was a more active and dynamic participant in demonstrations with self-denying dedication in the freedom struggle. Here Timothy has developed his critical stances by comparing intertextual relations. In fact his reference to the 'history book' adumbrates how 'intertextual frames' (Eco 1995, p. 200) can influence people's attitudes, values, and beliefs. This vividly demonstrates the fact that intertextuality should not be understood in terms of textual manifestations in a particular text alone; it should rather be extended even beyond the target text. Timothy's predilection for comparative analysis here is very significant from the point of view of critical orientations. Another striking aspect is that Timothy even transcends the contextual boundaries of a local situation to express his views in global contexts.

The fact that political leaders' utterances should be matched with action is also a critical proposition here. At times, Timothy unleashes his anger in rather provocative terms, 
but such comments are significant in the critical thinking process. His reference to 'religious leaders' is a deviation from the target text in order to be critical of some religious Discourses and such digressions should be appreciated and construed as vital in a listening/speaking class geared towards teaching critical thinking.

Similar digressions were made by Steven, too. When asked about the current issues, he referred to the slavery in fishing industry in Thailand, and his comments were very straightforward:

Excerpt 13.

Sometimes these people work more than 20 hours... yes almost all the day as labourers. They need freedom and good salaries....OK their work is dangerous, and some workers from Indonesia also suffer... It seems they are ignored. We don't have a leader like King. However, workers will stop working and strike... There is a decision like that...Very soon they will do it... Fishing people are very united and they all are in bad houses... poor education for their children. OK not a good picture...However they are in trouble and life is a problem for them from morning till night...

Steven refers to the exploitation of labour in the fishing industry and this is clearly a valid comparison to King's speech in regard to the emancipation of the black people. He even comments on the fishing community (a discourse community who shares similar discursive practices unique to them) and their discoursal identities in Thailand. Such propositions demonstrate Steven's critical aptitudes. The use of copulative verb 'seems' suggests another critical proposition: his desire not to be totally committed to what he comments on.

Taking up a global context, Steven refers to politicians who 'punish' people in 'some countries for nothing'. Here by using the textual resources of King's speech, Steven has developed critical stances to substantiate his claim, and this is also an instance of extended intertextuality. Similarly, Clara elaborated on women's liberation and such references to feminist discourses could also be recognized as part of extended intertextuality. Extended 
intertextual references stimulate students' mental reprints, thereby augmenting their critical thinking propensity. While extending intertextual links, some of our research participants also developed hypothetically significant stances through their critical observations. In these instances their social identities also played a significant role.

\section{Hypothetical Intertextuality}

Hypothetical intertextuality is characterized by students' ability to make critical judgments on a conjectural level. In these contexts, by intertextualizing into the future, students usually dwell on future possibilities and circumstances related to a current Discourse under review. Such critical attitudes signal the shift from one textual orientation to another in the process of making comparisons. Timothy's hypothetical assertion that 'young freedom fighters' will emerge from countries like China exemplifies how students hypothesize future possibilities: '...here the countries around us like China... there will be young freedom fighters as in some other countries...'. Timothy's reference to how 'past events' relate to 'the present' (through flashbacks) adumbrates the veracity of hypothetical propositions. These hypothetical judgments are often based on students' assumptions and speculations as part of critical thinking, often yoking a current situation/issue with a future possibility.

In the same vein, Clara contemplates future possibilities of empowering women in politics:

\section{Excerpt 14.}

In politics they have limited attention and we need more brave woman [women] leaders...International pressure is important. Developing countries can learn from international pressure through the media....and freedom will come little by little...

The emphasis placed on 'international pressure' for emancipating women in developing countries signals a future possibility realized through intertextual links integrated into the Discourse of liberating black people. 
Similarly, Steven surmises that it will take a long time before King's dreams are realized. Obviously the speech was convincing to Steven as evidenced by his conjectural proposition that King's dreams will be realized. His reference to possible strike action by the fishermen in Thailand also sheds some insights into the future.

Following the foregoing typology of intertextuality, the frequency in the use of intertextual links made by the participants may be summarized as follows: conceptual (15), apparent (7), extended (8), connotative (2), and hypothetical (3). This typology may act as a model for instructors to try out in a listening class; they may further develop similar typologically relevant manifestation of intertextuality based on target texts appealing to students identities. More importantly such typologies facilitate instructors to assess their students' critical thinking capacities in tangible ways.

\section{Discussion}

According to some scholars ((Elder \& Paul, 2004; Ennis, 1996; Fisher, 2001; Thompson, 2002; Walvoord \& McCarthy, 1990), people develop critical stances by resorting to various strategies and among them comparisons, evaluations, causality, and contestation play an important role. Self-realization through questioning is an equally important strategy. From a linguistic point of view, most of these critical stances are preceded by transition markers in utterances (e.g. however, but, although, on the other hand), and intertextually rich interactive texts provides students with ample opportunities for broadening their critical horizons. Our participants resorted to these strategies as evidenced by their responses to the interview questions.

From an ontological point of view, critical thinking can be classified into several levels. Counting on its conceptual integrity, Elder and Paul, for example, have identified five levels of critical thinking (2010). When considering the epistemological dimensions of critical thinking (i.e. to comprehend the complex forces, both mental and circumstantial, that lie behind the competence of critical thinking), it becomes evident that researchers have to 
embark on their investigations amidst intense subjectivity, and that such research should necessarily be backed by a huge corpus of empirical data. Hence, the level of critical thinking among our participants can be superficially rated as developmental. That is they have or are deemed to have potential for critical thinking, provided adequate pedagogical intervention is available.

Another related issue is the impact of L1 on critical thinking. Critical thinking is a mental process which belongs to linguistic domains associated with L1. Hence, L1 takes precedence over L2 in developing this skill. However, our students' listening/speaking skills were good enough to conceptualize intertextually realized knowledge capital in English using at times fragmented sentences. The provision of prior knowledge and also the questioning techniques used by the researchers facilitated these students to function in English, befitting their lower intermediate level. Hence, L2 proficiency is not considered to be a deterrent to their critical orientations. Critical thinking and critical expression are two different skills; the latter can be achieved at English for Academic Purposes (EAP) level.

Inadequate familiarity with the content of a text is a stumbling block for students. For example, none of our students was able to identify the excerpts from the Bible (Miller, 2007) which King used so lavishly in his speech for rhetorical as well as didactic purposes. Students should also be familiar with the intertextual references since they are mandatory for the meaning making process through participation in a variety of Discourse. References to Abraham Lincoln's Declaration of Independence highlight how knowledge of relevant intertextual links can be instrumental in the process of unravelling desired meanings of the target text.

Equally important aspect that can forge critical attitudes among students is their ideological orientations, affective dimensions, and socio-cultural imperatives which help them proceed beyond their comfort zones by making hypothetical propositions. Some of our research participants were able to harness their critical observations mostly by comparing the 
contents of King's speech with their knowledge of the issues of socio-economic and political significance, and social and discoursal identity peripheral to the contexts in which King's speech was anchored. Clara, for example, referred to the Tiananmen incidence in China which she had witnessed in a similar interactive text, and then extended her intertextualization to comment on the students who took refuge in Canada, USA, and Australia during that time. She also observed the presence of white people in the audience as a manifestation of the support for a worthy cause from King's perceived opponents. The presence of white people is only a physical phenomenon which can be extended to several Discourses (equal rights, human rights, racism etc.) in the context of King's speech. Depending on the resourcefulness of the instructor, such Discourses can be discussed by providing prior knowledge, if necessary, in particular reference to individual student needs. At several interviews, our participants' primary academic voice (utterances that demonstrate students' ability to conceptualize their own perceptions independently as opposed to repeating what they have learnt from secondary sources) predominantly surfaced.

Students' ability to synthesize intertextually realized Discourses with the themes of the target text is perhaps the most significant outcome of critical thinking. All our research participants at varying degrees were able to integrate intertextual links they were familiar with into the target text. The textual relations unravelled by students are by no means polarized; they are rather reciprocal entities that lend themselves to a variety of interpretations. Peripheral to this aspect is the opportunity for students to be fluent speakers capable of being engaged in productive intellectual discussions. Since our critical stances are mandatory for proper understanding of texts, intertextual resources are instrumental in developing such stances.

Selection of texts for enhancing critical aptitudes of students is pivotal. As Prensky (2001) points out, the impact of textual links on our routine work and self-identity in modern contexts has assumed enormous proportions as a result of the sophisticated products of new 
technologies of communication. It is also significant to note that some of our research participants (This could be applicable to a significant number of non-English speaking background university students in general regardless of geographical boundaries) whose knowledge of English was inadequate to comprehend King's use of ponderous phraseology were prone to depend more on the visual aspects of the text (e.g., posters, demonstrations) and make critical observations. This situation vindicates the use of visually mediated texts as a stepping stone for making lower intermediate level students think critically in listening/speaking classes.

Another significant aspect of developing critical stances among students is the questioning techniques designed towards unravelling intertextual links contained in a particular text. When framing their questions relating to a target text, instructors can play the role of an investigative journalist whose prime motive is to flesh out news items with the information derived from who-what-when-where-why-how technique. Even if the students' responses are short and curt, their attempts at making judgments, comparisons, arguments, and any comment in general should be encouraged since they all demand an element of critical thinking on the part of the students. In particular, it was through rigorous questioning (using statement questions and open-ended questions) that we were able to make Joe speak. Similarly, Park initiated his comments by repeating the lexical items contained in our question 'Why do people carry posters and display in public places?' ('People carry posters and display in public places...'). Such iterative episodes should not be taken as plagiaristic trends in students but as effective learning initiatives.

Asking students to provide examples of situations, people, and issues peripheral to the ones in a text can also persuade them to think critically. Some students commented on the need for community leaders to follow the example of King. And some were eager to unravel the hypocrisy of political leaders masquerading as emancipators of the masses. Such 
contesting voices of the students certainly pave the way for critical observation in their chosen environments.

Central to language pedagogy are a variety of carefully designed activities since they foster dynamic learning. Well-organized group work for example is a productive strategy for developing students' critical stances using interactive texts. In a debate environment for example students enjoy competing with each other, and passive listeners are motivated to be active participants. Such opportunities for collaborative learning should ideally stem from effective intertextually situated text models provided by the instructor. Question sessions where students ask and answer questions can lead to a discussion class quite appropriate for an EFL listening/speech class. In addition to critical thinking, group dynamics can also precipitate other dimensions such as competitiveness, cooperation, learning through errors, self-confidence etc. Moreover, a particular group itself is a pool of resources since students can use their varied biographical, social, discoursal, and ideological identities in establishing critical relations.

\section{Limitations}

Working towards a globally sustainable pedagogical paradigm can be a mammoth task enveloping global dimensions. To what extent we can extrapolate the results of this research to accommodate globally or even regionally defined student population is a problematic issue. Students in regions where access and affordability to new technologies of communication are limited may not have adequate exposure to visually mediated interactive texts.

Our research participants come from diverse ethnic background and this diversity shapes their attitudes, values, beliefs and experiences related to the interactive text under review. However, a mono-lingual or a mono-cultural group of students would most likely be devoid of such diverse approaches to a text. 
Furthermore, some instructors may not have the pedagogic desire to utilize interactive texts for enhancing students' critical thinking. There is sufficient evidence (Bean, 2011; Chaffee et al, 1999; Thompson, 2002)) to suggest that most instructors in EFL/EAP classes prefer to use reading/comprehension tasks geared towards students' critical thinking awareness.

Despite these limitations, our research has a strong appeal to a significant number of students whose identities are conditioned by discursive practices emerging from new technologies of communication.

\section{Conclusion}

In a tecnocentric globalized world, students are more prone to be engaged in visually mediated interactive texts with intertextual intensity as part of their life, being engaged in technology-based ritualistic discursive practices through interactive textual dynamics (e.g. electronic shopping, advertisements, texting etc.). Students have close intimacy with visually potent interactive learning materials in EFL classes and they can lead students towards developing critical stances with ease.

Since critical thinking precedes critical expression, students' ability to think critically can also assist them in producing analytical texts as opposed to descriptive ones, particularly in writing classes. The major implication here is that critical thinking is a skill we need to teach in a language class using various strategies that have strong affinity with and appeal to students' identities, and intertextuality is just one of them. Interactive texts, which lend themselves to a series of Discourse, are a breeding ground for intertextuality and critical thinking is required for unravelling relations between interactive texts and Discourse filtered through intertextuality. It is through pedagogical assistance that lower intermediate level students can comprehend the complexity inherent in interactive texts. In other words, various types of Discourse are disseminated by means of texts. Interactive texts in particular appeal to

digitally agile students in our contemporary contexts. It is however through pedagogical 
intervention that lower intermediate level students can capture the realms of critical thinking associated with intertextual links and their accompanying Discourse.

Hence, as far as metacognitive strategies are concerned, this research introduces a micro model that foregrounds the nexus between intertextuality, interactive texts, Discourse, critical thinking, and pedagogical intervention. Not only does the typology of intertextuality introduced here assist students in enhancing their critical thinking but it also helps instructors to assess where the students really stand in their critical thinking process and also to select materials that whet the appetite of students. In particular, the zest with which our research participants respond to Discourse in King's speech demonstrates the impact of interactive texts and their intertextual resources on their psyche. In fact, the visual potency in the target text is more palatable than its rhetorical rigor to lower intermediate or even intermediate level EFL students. There are ample opportunities for future researchers to investigate the role of intertextually rich interactive texts and their accompanying Discourse in galvanizing students' critical awareness. We propose that in these environments, 'interactive intertextuality' could be identified as a concept for teaching critical thinking in EFL classes in particular, and in other genres of language teaching classes in general. It is pertinent to note here that this concept can be applicable to language pedagogy regardless of the medium of instruction. 


\section{References}

Alagozlu, N. (2007). Critical Thinking and Voice in EFL Writing. Asian EFL Journal, 9 (3), 118 136.

Allen, G. (2000). Intertextuality. London: Routledge.

Althusser, L. (1977). Ideology and the state apparatus (Notes towards an investigation). In B.

Brewster (Trans.), Lenin and philosophy and other essays (pp.127-186). London: New Left Books.

Appadurai, A. (1996). Modernity at large: Cultural dimensions of modernity. Minneapolis: University of Minnesota Press.

Atkinson, D. (1997). A critical approach to critical thinking in TESOL. TESOL Quarterly, 31(1), 7995.

Bakhtin, M. M. (1981). The dialogic imagination. Four essays. C. Emerson., \& M. Holquist (Trans.). Austin: University of Texas Press.

Bakhtin, M. M. (1984). Problems of Dostoevsky's poetics. C. Emerson (Trans.). Minneapolis: University of Minnesota Press).

Bakhtin, M. M. (1986). Speech genres and other late essays. C. Emerson \& M. Holquist (Trans.). Austin: University of Texas Press.

Barthes, R. (1977). Image, music, text. S. Heath (Trans.). New York: Hill \& Wang.

Barthes, R. (1981). Theory of the text. In. R. Young (Ed.), Untying the text (pp. 31-47). London: Routledge.

Baudrillard, J. (1993). Symbolic exchange and death. I. Grant (Trans.).London: Sage Publications.

Bean, J. C. (2011). Engaging ideas: The professor's guide to integrating writing, critical thinking, and active learning in the classroom. San Francisco CA: John Wiley \& Sons.

Carter, R. 1993. Introducing applied linguistics. Harlow: Penguin.

Chaffee, J., McMahon, C., \& Stout, B. (1999). Critical thinking, thoughtful writing: A rhetoric with readings. Boston: Houghton Miffin Co.

Chandrasoma, R., \& Lee, J. E. (2013). A Current Approach to EFL Writing: Identity and Learning in the Classroom. Studies in English Language and Literature. 39 (3), 189-219.

Chandrasoma, R., Thompson, C., \& Pennycook, A. (2004). Beyond plagiarism: Transgessive and non-transgressive intertextuality. Journal of Language, Identity, and Education. 3 (3), 171193.

Chi, F. (1998). Intertextuality as a constructive reading strategy: Three successful Taiwanese EFL college cases. Studies in English Literature and Linguistics. 24, 49-62.

Christine, C. P., Varelas, M., Barry., A., \& Rife, A. (2002). Dialogic inquiry around information texts: The role of intertextuality in constructing scientific understandings in urban primary classrooms. Linguistics and Education, 13(4), 435-482. 
Davidson, B.W. (1998). A case for critical thinking in the English language classroom. TESOL quarterly, 32(1), 119-123.

Eco, U. (1995). Faith in fakes. London: Minerva.

Elder, L., \& Paul, R. (2004). Critical thinking and the art of close reading (part IV). Journal of Developmental Education, 28(2), 36-37.

Elder, L., \& Paul R. (2010). www.criticalthinking.org. (Date accessed: 15 April 2017).

Ennis, R. H. (1996). Critical Thinking. Upper Saddle Drive, N.J.: Prentice Hall.

Fairclough, N. (1995). Discourse and social change. Cambridge: Polity Press.

Fisher, A. (2001). Critical thinking: An introduction. New York: Cambridge University Press.

Gardner, H., \& Davis, K. (2013). The App Generation: How Today's Youth Navigate Identity, Intimacy, and Imagination in a Digital World. New Haven: Yale University Press.

Gee, J. P. (1996). Social linguistics and literacies: Ideology in discourses. London: Taylor \& Francis.

Gray, J. (2006). Watching with the Simpsons: Television, parody, and intertextuality. London: Routledge.

Ivanic, R. 1998. Writing and Identity. Amsterdam: John Benjamins Publishing Company.

King, M. L. Jr. (1963). The March on Washington August 28, 1963. https://www.youtube.com/watch?v=H0yP4aLyq1g (Accessed June 22, 2015).

Klein, M. L. (2005). Intertextuality in western art music. Bloomington: Indiana University Press.

Kline, T. J. (1992). Screening the text: Intertextuality in the new wave of French cinema. Baltimore, MD: John Hopkins University.

Knobel, M. (1999). Everyday literacies: Students, discourse, and social practice. New York: Peter Lang.

Kristeva, J. (1980). Desire in language: A semiotic approach to literature and art. T. Jardine., T. Gora., \& L. S. Roudiez (Trans.). New York: Columbia University Press.

Kristeva, J. (1984). The revolution in poetic language. M. Walker (Trans.). New York: Columbia University Press.

McCarthy, M. (1991). Discourse analysis for Language Teachers: Cambridge: Cambridge University Press.

McCarthy, M. \& Carter, R. (1994). Language as Discourse: Perspectives for Language Teaching. London: Longman.

McKinley, J. (1991). Displaying Critical Thinking in EFL Academic Writing: A Discussion of Japanese to English Contrastive Rhetoric. RELC Journal. 44 (2). 195-208.

Miller, K.D. (2007). Second Isaiah lands in Washington, DC; Martin Luther King, Jr's 'I have a Dream' as Biblical Narrative and Biblical Hermeneutic. Rhetoric Review, 405-424.

Miola, R.S. (2004). Seven Types of Intertextuality. Manchester: Manchester University Press. 
Nielsen, A.L. (1994). Writing between the lines: Race and intertextuality. Athens, GA: University of Georgia Press.

Norton, B. (2000). Identity and language learning: Gender, ethnicity, and educational change. Essex: Pearson Education.

Nunan, D. (1993). Introducing discourse analysis. London: Penguin.

Oster, J. (1989). Seeing with different eyes: Another view of literature in the ESL class. TESOL Quarterly, 23(1), 85-103.

Pennycook, A. (1990). Critical pedagogy and second language education. System, 18 (3), 303-314.

Prensky, M. (2001). Native digital immigrants. Part 1. On the Horizon, 9(5), 1-6.

Saussure, F. de. (1974). Course in general linguistics. In C. Bally \& A. Sechehaye. (Eds.). W. Baker. London: Owen.

Thompson, C. (2002). Teaching critical thinking in English for academic purposes courses in Australia. TESOL Journal, 11(4), 15-20.

Walvoord, B.E., \& McCarthy, L.P. (1990). Thinking and writing in college: A naturalistic study of students in four disciplines. Urbana IL: National Council of Teachers of English.

Yu, P. (2013). Critical Thinking in a University EFL Classroom. Asian EFL Journal.71, 4-30.

Zheng, S. (2014). A Stylistic Analysis on 'I Have A Dream.' Journal of Studies in Social Sciences. 9 (1), 123-134. 


\section{Appendix}

Questions targeting themes and concepts

What's the most important issue here? What does Dr King repeat several times?

What's his dream?

Why does he repeat 'I have a dream'?

Could you give me an example?

Dreams and realities are two different things. What's your opinion related to Dr King's speech?

Questions that demonstrate salient characteristics of Dr King's speech

In what ways does Dr King develop his speech?

How does Dr King persuade his audience?

What examples does he provide?

What about his body language?

Questions focusing on the visual aspects of the speech and their intertextual links

How about the visual aspects? What were the most attractive images?

Could you give us more details about the visual images?

Why did they carry posters?

Why do some students in demonstrations carry posters?

What do you think of the presence of white people in the audience?

What do you think of the audience? What was their response?

Questions which persuade students to make comparisons

Do you know of any other people like Dr King? Who are they? Tell us about them?

What issues can you think of other than the ones Dr King is talking about?

You said some political leaders make such speeches. Who else usually makes such speeches?

Could you relate this to other similar events you remember?

Questions centred on political discourse

So, this is a political speech. Isn't it? What do you think?

Dr King talks about democracy. What do you think of democracy? Any references to democracy in the text?

What's dictatorship? Can you name some dictators?

Questions that necessitate conjectures

How about having leaders like Dr King in the future?

Women's freedom? When can they achieve freedom in developing countries? 